\title{
ТЕРАПІЯ
}

https://doi.org/10.35339/msz.2019.83.02.03

УДК 616.36-003.826-092:616.12-008.331.1

О.Я. Бабак, К.О. Просоленко, В.І. Молодан, Г.Ю. Панченко, К.А. Лапшина

Харківський національний медичний університет

\section{ОСОБЛИВОСТІ ПОРУШЕНЬ ВУГЛЕВОДНОГО Й ЛІПІДНОГО ОБМІНІВ ПРИ НЕАЛКОГОЛЬНІЙ ЖИРОВІЙ ХВОРОБІ ПЕЧІНКИ ТА IIÏ КОМОРБІДНОСТІ 3 АРТЕРІАЛЬНОЮ ГІПЕРТЕНЗІЄЮ}

\begin{abstract}
Досліджено особливості вуглеводного й ліпідного обмінів за коморбідності неалкогольної жирової хвороби печінки та гіпертонічної хвороби або ренопаренхіматозної артеріальної гіпертензії, оцінено основні фактори, що впливають на ці показники. Обстежено 269 пацієнтів: 60 - із неалкогольною жировою хворобою печінки, 121 - із коморбідністю такої і гіпертонічної хвороби, 88 - із її коморбідністю із ренопаренхіматозною артеріальною гіпертензією, середній вік пацієнтів - $(48,07 \pm 10,81)$ року. Контрольна група - 20 здорових осіб, порівнянних за віком і статтю із хворими. Оцінювали антропометричні дані й артеріальний тиск. Визначали концентрацію ліпідів крові, амінотрансферази, гамма-глутамілтранспептидази, інсуліну, глікозильований гемоглобін та інші біохімічні показники крові, інсулінорезистентність за індексом НОМА, швидкість клубочкової фільтрації. Використовували ультразвукове дослідження. Виявлено, що для пацієнтів із неалкогольною жировою хворобою печінки незалежно від іїі коморбідності 3 гіпертонічною хворобою або ренопаренхіматозною артеріальною гіпертензією характерні порушення вуглеводного й ліпідного обмінів. Коморбідність спричинює посилення цих змін, що відіграє важливу роль у патогенезі захворювань. Показники тригліцеридів та індексу НОМА достовірно вищі за коморбідності як із гіпертонічною хворобою, так і з ренопаренхіматозною артеріальною гіпертензією. Показники ліпопротеїдів низької щільності достовірно вищі за коморбідності з ренопаренхіматозною артеріальною гіпертензією. Показники вуглеводного й ліпідного обмінів тісно пов'язані з показниками артеріального тиску, індексами маси тіла й талія / стегно, маркерами ураження печінки, нирковою функцією, а також тривалістю захворювання. Спектр кореляційних зв'язків є різним у хворих з ізольованою неалкогольною жировою хворобою печінки та за ії коморбідності. За коморбідності характерними є кореляційні взаємозв'язки між показниками вуглеводного й ліпідного обмінів, з одного боку, та показниками артеріального тиску й ниркової функції - із другого. Дані зміни свідчать про найбільший проатерогенний потенціал у хворих із коморбідним перебігом хвороби, що в поєднанні 3 порушеннями вуглеводного обміну призводить до значного зростання кардіоваскулярного ризику й цукрового діабету 2-го типу.
\end{abstract}

Ключові слова: дисліпідемія, порушення вуглеводного обміну, неалкогольна жирова хвороба печінки, артеріальна гіпертензія.

Зв'язок роботи 3 науковими програмами, планами, темами

Дослідження виконано в рамках науководослідної роботи кафедри внутрішньої медицини № 1 ХНМУ «Оптимізувати діагностику та корекцію судинних уражень у хворих на гіпертонічну хворобу у поєднанні з ожирінням на основі вивчення функціонального стану ендотелію та генетичних порушень» (номер держреєстрації 011U002385) та «Оптимізація ліку-

(C) О.Я. Бабак, К.О. Просоленко, В.І. Молодан та ін., 2019 
вання неалкогольної жирової хвороби печінки на тлі гіпертонічної хвороби з урахуванням метаболічних, судинних аспектів та поліморфізму гена AGTR1» (номер держреєстрації 015U000236).

\section{Вступ}

Безперечна актуальність вивчення неалкогольної жирової хвороби печінки (НАЖХП) зумовлена найбільшою ії розповсюдженістю з усіх хронічних хвороб печінки в Європі та світі $[1,2]$. У великої кількості пацієнтів із НАЖХП спостерігається коморбідність ії 3 гіпертонічною хворобою (ГХ) та вторинною артеріальною гіпертензією (АГ). Дослідженими та доведено важливими в патогенезі НАЖХП і ГХ є порушення вуглеводного й ліпідного обмінів [3, 4]. Відомо, що в основі патогенезу НАЖХП лежить зниження чутливості тканин до інсуліну, а порушення вуглеводного обміну $є$ самостійними факторами кардіоваскулярного ризику $[5,6]$. Крім того, загальновідомим $є$ тісний зв'язок між підвищенням проатерогенних ліпідів і тяжкістю ураження артерій за АГ [2, 7]. Гіпертригліцеридемія і проатерогенна дисліпідемія мають суттєве значення як у виникненні НАЖХП, так і в iї прогресуванні $[3,5]$.

Між іншим, залишаються недостатньо дослідженими особливості вуглеводного й ліпідного обмінів за коморбідності НАЖХП та ГХ або ренопаренхіматозної АГ (РПАГ). Унаслідок порушення ниркової функції як за ізольованої НАЖХП, так і за їі коморбідності з ГХ / РПАГ зміни ліпідного й вуглеводного обмінів можуть також впливати на ці параметри [6].

Мета даного дослідження - установити особливості вуглеводного й ліпідного обмінів за коморбідності НАЖХП та ГХ або РПАГ, а також оцінити основні фактори, що впливають на ці показники.

\section{Матеріал і методи}

Дослідження проводили на базі відділення гастроентерології та терапії, а також поліклініки ДУ «Національний інститут терапії імені Л.Т. Малої НАМН України» (м. Харків). Клінічні й біохімічні дослідження виконували в клініко-діагностичній лабораторії ДУ «Національний інститут терапії імені Л.Т. Малої НАМН України» та лабораторії «Альфа Лабсервіс», функціональні дослідження - у відділенні функціональної та ультразвукової діагностики.
Об'єктом дослідження були 269 пацієнтів, які ввійшли у три групи: 1-ша - 60 пацієнтів 3 ізольованою НАЖХП; 2-га - 121 пацієнт із коморбідністю НАЖХП та ГХ ІІ стадії, 2-го ступеня; 3-тя - 88 пацієнтів із коморбідністю НАЖХП та РПАГ ІІ стадії, 2-го ступеня, які знаходились на стаціонарному й амбулаторному лікуванні. Вік пацієнтів становив від 18 до 66 років, середній вік пацієнтів - $(48,07 \pm$ $10,81)$ року. Серед обстежених 53,9 \% становили чоловіки і 46,1 \% - жінки. Розподіл хворих за статтю був рівномірний.

Ренопаренхіматозну АГ у всіх пацієнтів діагностовано як наслідок хронічного пієлонефриту, який на момент дослідження був у ремісії. Крім того, у цих пацієнтів не було значного зниження швидкості клубочкової фільтрації (ШКФ), ступінь хронічної хвороби нирокI-III.

У дослідження не включали хворих із цукровим діабетом 1-го та 2-го типів, іншими дифузними та вогнищевими захворюваннями печінки (вірусними гепатитами, алкогольною хворобою печінки, цирозом печінки та ін.), іншою супутньою патологією в пацієнтів із НАЖХП: ішемічною хворобою серця, ревматичними вадами серця, онкологічними захворюваннями, системними захворюваннями сполучної тканини, хронічною серцевою недостатністю ІІБ-ІІІ стадії, АГ 1-го та 3-го ступенів, ГX I та III стадій, ехонегативністю, вагітністю та лактацією, а також у разі відмови від дослідження.

Контрольну групу становили 20 здорових осіб, порівнянних з обстеженими хворими за віком та статтю.

Клінічне обстеження хворих полягало в оцінюванні параметрів об'єктивного огляду, зокрема антропометричних даних та артеріального тиску (АТ), стандартними методиками.

Для діагностики неалкогольного стеатозу використовували ультразвуковий метод дослідження на ультразвуковій діагностичній системі «GE» (США). Визначали краніокаудальні розміри правої і лівої частин печінки, довжину i ширину жовчного міхура, довжину і ширину селезінки. Визначали три ступені стеатозу печінки. Ступінь стеатозу печінки встановлювали за даними ультразвукового дослідження: I - незначне підвищення ехогенності паренхіми печінки, нормальна візуалізація внутрішньопечінкових судин і діафрагми; II - помірне 
дифузне підвищення ехогенності паренхіми печінки, незначне порушення візуалізації внутрішньопечінкових судин та діафрагми; III - виражене підвищення ехогенності паренхіми печінки, візуалізація внутрішньопечінкових судин, діафрагми та задньої частини правої частки значно порушена або взагалі відсутня. У частини пацієнтів (212 осіб) стеатоз печінки було підтверджено тестом «Фібромакс» (Франція).

Концентрацію загального холестерину (3ХC) та його фракцій: ХC ліпопротеїдів високої (ХС ЛПВЩ), низької (ХС ЛПНЩ) та дуже низької (ХС ЛПДНЩ) щільності - та тригліцеридів (ТГ) визначали ферментативним методом на біохімічному аналізаторі «Humalayzer 2000» (Німеччина) із використанням набору реактивів фірми «Нuman» та «Соrmay» (Німеччина). Інші біохімічні показники крові: вміст амінотрансфераз (АСТ, АЛТ), гамма-глутамілтранспептидази (ГГТП), глюкози, глікозильованого гемоглобіну та інсуліну - визначали стандартними загальноприйнятими методами. Крім того, вираховували індекс НОМА. Швидкість клубочкової фільтрації визначали за формулою CKD-EPI.

Статистичну обробку результатів проводили за допомогою комп'ютерних програм Microsoft Excel та Statistica 3 використанням стандартних методів варіаційної статистики. Для оцінювання достовірності різниці при парних змінах показників використовували t-критерій Ст'юдента $(\mathrm{M} \pm \sigma)$. Різницю вважали статистично достовірною за $\mathrm{p}<0,05$.

\section{Результати та їх обговорення}

У хворих на НАЖХП усіх груп спостерігались порушення вуглеводного обміну, що проявлялись підвищенням рівнів глікемії натще, інсуліну, індексу НОМА та глікозильованого гемоглобіну відносно показників групи контролю. При цьому всі ці пацієнти не мали цукрового діабету. Слід зазначити, що більшість обстежених пацієнтів мали надлишкову масу тіла або ожиріння. Так, у пацієнтів 1-ї групи індекс маси тіла (IMT) дорівнював $(29,69 \pm$ $2,82) \kappa \Gamma / \mathrm{M}^{2}$, у хворих 2-їгрупи - $(31,50 \pm 3,69) \kappa \Gamma / \mathrm{M}^{2}$, а в обстежених 3-ї групи - $(31,96 \pm 3,65) \kappa г / \mathrm{M}^{2}$.

У осіб групи контролю порушень ліпідного й вуглеводного обмінів не спостерігалось (табл. 1).

У хворих на НАЖХП 1-ї групи мали місце порушення вуглеводного обміну, що проявлялись, зокрема, підвищенням рівнів глікемії натще. Так, середні показники глікемії натще в обстежених хворих 1-ї групи становили $(5,41 \pm$ $0,59)$ ммоль/л та достовірно перевищували відповідний показник групи контролю $(4,88 \pm 0,40)$ ммоль/л $(\mathrm{p}<0,001)$. Між іншим, не було різниці між показниками хворих 1-ї групи та хворих 2-ї й 3-ї груп і контролю (p>0,05). Рівні глікозильованого гемоглобіну в пацієнтів 1-, 2- та 3-ї груп достовірно перевищували відповідні показники практично здорових осіб $(5,11 \pm 0,37) \%$ та знаходились на рівні $(5,76 \pm$ $0,65),(5,83 \pm 0,23)$ та $(5,87 \pm 0,19) \%$ відповідно. При цьому дані показники між собою достовірно не розрізнялись $(\mathrm{p}>0,05)$.

Дуже важливим фактором патогенезу НАЖХП $є$ інсулінорезистентність. У наших пацієнтів він був підвищеним і суттєво перевищував показник обстежених групи контролю $(\mathrm{p}<0,001)$. Так, індекс НОМА становив $3,76 \pm 0,76$ у хворих 1-ї групи та був достовірно нижчим за такий у хворих 2-ї та 3-ї груп, де він становив $4,00 \pm 0,79$ та $4,06 \pm 0,73$ відповідно

Таблиия 1. Основні показники вуглеводного й ліпідного обмінів у обстежених хворих

\begin{tabular}{l|c|c|c|c}
\hline \multirow{2}{*}{\multicolumn{1}{c|}{ Показник }} & \multicolumn{3}{|c}{ Група обстежених } \\
\cline { 2 - 5 } & $\begin{array}{c}\text { контрольна } \\
(\mathrm{n}=20)\end{array}$ & $\begin{array}{c}1 \text {-ша } \\
(\mathrm{n}=60)\end{array}$ & $\begin{array}{c}2-\text { га } \\
(\mathrm{n}=121)\end{array}$ & $\begin{array}{c}3-\text {-тя } \\
(\mathrm{n}=88)\end{array}$ \\
\hline Глюкоза крові, ммоль/л & $4,88 \pm 0,40$ & $5,41 \pm 0,59^{*}$ & $5,52 \pm 0,51$ & $5,64 \pm 0,54$ \\
Інсулін крові, мкОд/мл & $8,41 \pm 1,27$ & $15,58 \pm 2,55^{*}$ & $16,25 \pm 2,49$ & $16,18 \pm 2,35$ \\
НОМА & $1,82 \pm 0,28$ & $3,76 \pm 0,76^{*} @$ & $4,00 \pm 0,79$ & $4,06 \pm 0,73$ \\
Глікозильований гемоглобін, \% & $5,11 \pm 0,37$ & $5,76 \pm 0,65^{*}$ & $5,83 \pm 0,23$ & $5,87 \pm 0,19$ \\
ЗХС, ммоль/л & $4,49 \pm 0,38$ & $5,76 \pm 0,90^{*}$ & $5,81 \pm 1,01$ & $5,98 \pm 0,84$ \\
ТГ, ммоль/л & $0,96 \pm 0,26$ & $1,88 \pm 0,74^{*} @$ & $2,12 \pm 0,70$ & $2,23 \pm 0,95$ \\
ХС ЛПДНЩ, ммоль/л & $0,55 \pm 0,22$ & $0,77 \pm 0,39^{*}$ & $0,83 \pm 0,67$ & $0,90 \pm 0,53$ \\
ХС ЛПВЩ, ммоль/л & $1,53 \pm 0,24$ & $1,21 \pm 0,27^{*}$ & $1,24 \pm 0,28$ & $1,24 \pm 0,38$ \\
ХС ЛПНЩ, ммоль/л & $2,65 \pm 0,41$ & $3,68 \pm 0,85^{*} @$ & $3,87 \pm 0,96$ & $3,99 \pm 0,87$ \\
Коесріцієнт атерогенності & $1,99 \pm 0,36$ & $3,93 \pm 1,15^{*}$ & $3,91 \pm 1,12$ & $4,14 \pm 1,41$ \\
\hline
\end{tabular}

Прилітка. Різниця достовірна при порівнянні з показниками: * контролю; \# 2-ї групи; @ 3-ї групи. 
$(\mathrm{p}<0,05)$. Виявлені зміни можуть свідчити про високий продіабетогенний потенціал у пацієнтів із НАЖХП, особливо за коморбідності iii 3 ГХ/РПАГ.

При аналізі показників ліпідного обміну у хворих усіх трьох груп було встановлено суттєві зміни ліпідограми (табл. 1). Дисліпідемію та/або прийом статинів було виявлено у $118(97,52 \%)$ пацієнтів 2-їгрупи та 87 (98,86\%) хворих 3-ї групи.

Щодо показників ліпідного обміну в обстежених пацієнтів 1-ї групи, вони всі, крім ЛПВЩ, перевищували показники контрольної групи. У хворих 1-ї групи рівень $3 Х \mathrm{XC} \mathrm{у} \mathrm{крові}$ був у межах $(5,76 \pm 0,90)$ ммоль/л та достовірно не відрізнявся від показників обстежених 2-ї та 3-ї груп - $(5,81 \pm 1,01)$ та $(5,98 \pm 0,84)$ ммоль/л відповідно ( $>0,05)$, але значно відрізнявся від контрольного - $(4,49 \pm 0,38)$ ммоль/л $(\mathrm{p}<0,001)$.

Тригліцериди відіграють дуже важливу роль у патогенезі НАЖХП. Їхній вміст був збільшеним у пацієнтів усіх трьох груп та значно перевищував показник групи контролю $(0,96 \pm 0,26)$ ммоль/л. Концентрація ТГ у пацієнтів з ізольованою НАЖХП становила $(1,88 \pm 0,74)$ ммоль/л та була достовірно нижчою, ніж в обстежених $2-і ̈-(2,12 \pm 0,70)$ ммоль/л $(\mathrm{p}<0,05)$ та 3-ї групи - $(2,23 \pm 0,95)$ ммоль/л $(\mathrm{p}<0,05)$. Концентрація ХС ЛПДНЩу хворих 1-ї групи становила $(0,77 \pm 0,39)$ ммоль/л і до- стовірно відрізнялась від показника групи контролю - $(0,55 \pm 0,22)$ ммоль/л $(\mathrm{p}<0,05)$. Визначено і відповідні зміни рівня ХС ЛПНЩу крові, дуже важливої проатерогенної фракції: концентрація ХС ЛПНЩ у хворих 1-ї групи - $(3,68 \pm$ $0,85)$ ммоль/л достовірно не відрізнялась від показників хворих 2-ї групи - $(3,87 \pm 0,96)$ ммоль/л ( $>0,05)$, але була меншою за показник обстежених 3 -ї групи - $(3,99 \pm 0,87)$ ммоль/л $(\mathrm{p}<0,05)$.

Протилежні зміни відбувались у рівні ХC ЛПВЩ у крові. У хворих на НАЖХП визначались низькі концентрації ХС ЛПВЩ. Середні значення ХС ЛПВЩ у хворих 1-ї групи становили $(1,21 \pm 0,27)$ ммоль/л. Вони були достовірно нижчими за відповідні показники практично здорових осіб - $(1,53 \pm 0,24)$ ммоль/л $(\mathrm{p}<0,001)$ та достовірно не відрізнялись від таких у хворих на НАЖХП із коморбідністю ГХ або РПАГ ( $>0,05)$.

Нами було вивчено кореляційні зв'язки між тривалістю нозологій, деякими антропометричними показниками, рівнями АСТ, АЛТ, ГГТП, креатиніну, ШКФ та власне показниками вуглеводного й ліпідного обмінів. Аналізували попарно всі показники окремо в пацієнтів трьох груп. Пари тільки суттєво корелюючих показників наведено в табл. 2-4.

У хворих 1-ї групи спостерігались тісні кореляційні зв'язки між тривалістю НАЖХП та показниками вуглеводного обміну. Так, вияв-

Таблиия 2. Кореляційні зв'язки між основними показниками пацієнтів 1-ї групи

\begin{tabular}{l|c|c}
\hline \multicolumn{1}{c|}{ Пара показників, що вагомо корелюють } & Коефіцієнт кореляції & Рівень значущості $(\mathrm{p})$ \\
\hline Тривалість НАЖХП / глюкоза крові & 0,312 & $<0,05$ \\
Тривалість НАЖХП / інсулін крові & 0,316 & $<0,05$ \\
Тривалість НАЖХП / НОМА & 0,403 & $<0,01$ \\
ІТС / інсулін крові & 0,362 & $<0,01$ \\
ІТС / НОМА & 0,298 & $<0,05$ \\
ІМТ / ЗХС & 0,335 & $<0,01$ \\
ІМТ / глюкоза крові & 0,273 & $<0,05$ \\
ІМТ / інсулін крові & 0,286 & $<0,05$ \\
ІМТ / НОМА & 0,364 & $<0,01$ \\
АЛТ / ЗХС & 0,328 & $<0,05$ \\
АЛТ / ТГ & 0,328 & $<0,05$ \\
АЛТ / глюкоза крові & 0,378 & $<0,01$ \\
АЛТ / інсулін крові & 0,437 & $<0,001$ \\
АЛТ / НОМА & 0,571 & $<0,001$ \\
ГГТП / ЗХС & 0,298 & $<0,05$ \\
ГГТП / глюкоза крові & 0,323 & $<0,05$ \\
ГГТП / інсулін крові & 0,354 & $<0,01$ \\
ГГТП / НОМА & 0,466 & $<0,001$ \\
ЗХС / глюкоза крові & 0,343 & $<0,01$ \\
ЗХС / НОМА & 0,322 & $<0,05$ \\
ТГ / НОМА & 0,331 & $<0,05$ \\
Глюкоза крові / нОМА & 0,595 & $<0,001$ \\
\hline
\end{tabular}


Таблиия 3. Корелячійні зв'язки між основними показниками пацієнтів 2-ї групи

\begin{tabular}{|c|c|c|}
\hline Пара суттєво корелюючих показників & Коефріцієнт кореляції & Рівень значущості (p) \\
\hline Вік / інсулін крові & 0,189 & $<0,05$ \\
\hline Тривалість ГХ / інсулін крові & 0,250 & $<0,01$ \\
\hline Тривалість ГХ / НОМА & 0,233 & $<0,01$ \\
\hline IMT / 3XC & 0,187 & $<0,05$ \\
\hline IMT / глюкоза крові & 0,205 & $<0,05$ \\
\hline IMT / HOMA & 0,228 & $<0,05$ \\
\hline IMT / глікозильований гемоглобін & 0,227 & $<0,05$ \\
\hline САТ / інсулін крові & 0,318 & $<0,001$ \\
\hline CAT / HOMA & 0,328 & $<0,001$ \\
\hline САТ / глікозильований гемоглобін & 0,371 & $<0,001$ \\
\hline САТ / TГ & 0,220 & $<0,05$ \\
\hline ДАТ / інсулін крові & 0,226 & $<0,05$ \\
\hline ДАТ / НOMA & 0,225 & $<0,05$ \\
\hline ДАТ / глікозильований гемоглобін & 0,210 & $<0,05$ \\
\hline АЛТ / глюкоза крові & 0,340 & $<0,001$ \\
\hline АЛТ / інсулін крові & 0,247 & $<0,01$ \\
\hline АЛТ / НОМА & 0,353 & $<0,001$ \\
\hline 3XC / TГ & 0,378 & $<0,001$ \\
\hline Глюкоза крові / інсулін крові & 0,228 & $<0,05$ \\
\hline Глюкоза крові / НОМА & 0,652 & $<0,001$ \\
\hline Глюкоза крові / глікозильований гемоглобін & 0,238 & $<0,01$ \\
\hline Глюкоза крові / креатинін крові & 0,204 & $<0,05$ \\
\hline Інсулін крові / НОМА & 0,884 & $<0,001$ \\
\hline Інсулін крові / глікозильований гемоглобін & 0,191 & $<0,05$ \\
\hline НОМА / глікозильований гемоглобін & 0,258 & $<0,01$ \\
\hline HOMA / ШКФ & $-0,223$ & $<0,05$ \\
\hline Глікозильований гемоглобін / креатинін крові & 0,278 & $<0,01$ \\
\hline Глікозильований гемоглобін / ШКФ & $-0,264$ & $<0,01$ \\
\hline
\end{tabular}

Таблиия 4. Кореляційні зв'язки між основними показниками пацієнтів 3-ї групи

\begin{tabular}{l|c|c}
\hline \multicolumn{1}{c|}{ Пара суттєво корелюючих показників } & Коефріцієнт кореляції & Рівень значущості (р) \\
\hline Вік / інсулін крові & 0,189 & $<0,05$ \\
Тривалість ГХ / інсулін крові & 0,250 & $<0,01$ \\
Тривалість ГХ / НОМА & 0,233 & $<0,01$ \\
IМТ / ЗХС & 0,187 & $<0,05$ \\
IМТ / глюкоза крові & 0,205 & $<0,05$ \\
IМТ / НОМА & 0,228 & $<0,05$ \\
ІМТ / глікозильований гемоглобін & 0,227 & $<0,05$ \\
САТ / інсулін крові & 0,318 & $<0,001$ \\
САТ / НОМА & 0,328 & $<0,001$ \\
САТ / глікозильований гемоглобін & 0,371 & $<0,001$ \\
САТ / ТГ & 0,220 & $<0,05$ \\
ДАТ / інсулін крові & 0,226 & $<0,05$ \\
ДАТ / НОМА & 0,225 & $<0,05$ \\
ДАТ / глікозильованй гемоглобін & $<0,05$ \\
АЛТ / глюкоза крові & 0,210 & $<0,001$ \\
АЛТ / інсулін крові & 0,340 & $<0,01$ \\
АЛТ / НОМА & 0,247 & $<0,001$ \\
ЗХС / ТГ & 0,353 & $<0,001$ \\
Глюкоза крові / інсулін крові & 0,378 & $<0,05$ \\
Глюкоза крові / НОМА & $<0,001$ \\
Глюкоза крові / глікозильований гемоглобін & 0,228 & $<0,01$ \\
Глюкоза крові / креатинін крові & 0,652 & $<0,05$ \\
Інсулін крові / НОМА & 0,238 & $<0,001$ \\
Інсулін крові / глікозильований гемоглобін & 0,204 & $<0,05$ \\
НОМА / глікозильований гемоглобін & 0,884 & $<0,01$ \\
НОМА / ШКФ & 0,191 & $<0,05$ \\
Глікозильований гемоглобін / креатинін крові & 0,258 & $<0,01$ \\
Глікозильований гемоглобін / ШКФ & $<, 223$ & $<0,01$ \\
\hline
\end{tabular}


лено позитивний кореляційний зв' язок середньої сили між НОМА та тривалістю НАЖХП $+0,403(\mathrm{p}<0,01)$. Порушення вуглеводного й ліпідного обмінів позитивно корелювали з індексом талія / стегно та IMT, що може вказувати на важливу роль ожиріння в патогенезі НАЖХП. Крім того, $з$ огляду на позитивний кореляційний зв' язок між показниками вуглеводного (більшою мірою) та ліпідного обмінів iз показниками ураження печінки можна казати про вагому роль цих порушень у патогенезі й розвитку НАЖХП. Також було виявлено позитивні кореляційні зв' язки між показниками НОМА, вмісту ЗХС, ТГ та глюкози крові.

Вагомого зв'язку між АТ та показниками ліпідного й вуглеводного обмінів у пацієнтів 1-їгрупи не виявлено. Між іншим, у обстежених 2-ї групи було відмічено позитивний кореляційний зв' язок між САТ і ДАТ та показниками ліпідного (ТГ) та вуглеводного обмінів. У хворих 3-ї групи спостерігались аналогічні зміни.

При аналізі показників у пацієнтів 2-ї групи виявлено зв' язок між порушеннями вуглеводного й ліпідного обмінів із віком, тривалістю ГХ. Із тривалістю захворюваності на НАЖХП такого зв'язку не спостерігалось. Крім того, на відміну від отриманих даних у пацієнтів 1-ї групи, суттєвих кореляційних зв'язків між показниками вуглеводного обміну, з одного боку, та показниками ліпідного обміну - із другого, не виявлено.

При цьому показники вуглеводного обміну впливали на ниркову функцію. Так, глікозильований гемоглобін позитивно корелював 3 показником креатиніну $-0,278(\mathrm{p}<0,01)$ та негативно - зі ШКФ - -0,264 ( $<0,01)$. Індекс НОМА мав слабкий кореляційний зв'язок із ШКФ - -0,223 $(\mathrm{p}<0,05)$.
Проаналізовано кореляційні зв'язки в пацієнтів 3-ї групи. Виявлено позитивні кореляційні зв'язки між показниками вуглеводного обміну й віком, тривалістю РПАГ та НАЖХП. Збільшення маси тіла було пов'язано зі збільшенням рівня $3 \mathrm{XC}$ у крові, НОМА та глікозильованого гемоглобіну. Виявлено кореляційні позитивні зв'язки між ДАТ і САТ та вмістом ТГ $-+0,223(\mathrm{p}<0,05)$ та $+0,258(\mathrm{p}<0,05)$ відповідно. Зв'язку між вмістом АЛТ і ГГТП, з одного боку, та показниками ліпідного й вуглеводного обмінів - із другого, не виявлено, але мав місце значущий зв' язок між вмістом АСТ та ТГ $-+0,360(\mathrm{p}<0,001)$.

Нами встановлено позитивні взаємозв'язки між показниками вуглеводного й ліпідного обмінів між собою. Показники як ліпідного, так вуглеводного обміну корелювали з вмістом креатиніну та ШКФ. Так, у пацієнтів 3-ї групи ШКФ негативно корелювала 3 індексом HOMA - $-0,291(\mathrm{p}<0,01)$.

Наступним етапом дослідження було визначення в усіх наших хворих за допомогою однофакторного односпрямованого дисперційного аналізу ANOVA, наскільки ступінь стеатозу впливає на показники ліпідного й вуглеводного обмінів. Визначали F-коефіцієнт Фішера (табл. 5). Установлено, що ступінь стеатозу печінки впливає на показники як вуглеводного, так і ліпідного обміну. За показником цукру крові коефіцієнт Фішера дорівнював $\mathrm{F}=10,40(\mathrm{p}<0,001)$, за показником інсуліну крові - F=25,22 ( $<00,001)$, за показником HOMA - F=33,662 (p<0,001), за показником $3 \mathrm{XC}-\mathrm{F}=8,87(\mathrm{p}<0,001)$, за коефіцієнтом атерогенності $-\mathrm{F}=3,44(\mathrm{p}<0,05)$. Такі результати свідчать про суттєву роль порушень вуглеводного й ліпідного обмінів у прогресуванні

Таблиия 5. Показники однофакторного дисперсійного аналізу ANOVA у досліджених пацієнтів з НАЖХП

\begin{tabular}{l|c|c}
\hline \multirow{2}{*}{ Показник } & \multicolumn{2}{|c}{ Ступінь стеатозу } \\
\cline { 2 - 3 } & F-коефіцієнт Фішера & Рівень значущості (p) \\
\hline Глюкоза крові & $=10,40$ & $<0,001$ \\
Інсулін крові & $=25,22$ & $<0,001$ \\
НОМА & $=33,662$ & $<0,001$ \\
Глікозильований гемоглобін & $=0,56$ & $>0,05$ \\
3ХС & $=8,87$ & $<0,001$ \\
ТГ & $=2,494$ & $>0,05$ \\
ЛПДНЩ & $=1,03$ & $>0,05$ \\
ЛПВЩ & $=0,16$ & $>0,05$ \\
ЛПНЩ & $=1,19$ & $>0,05$ \\
Коефіцієнт атерогенності & $=3,44$ & $<0,05$ \\
\hline
\end{tabular}


НАЖХП за наявності або відсутності коморбідності з ГХ / РПАГ.

\section{Висновки}

1. Для пацієнтів із неалкогольною жировою хворобою печінки незалежно від наявності їі коморбідності з гіпертонічною хворобою або ренопаренхіматозною артеріальною гіпертензією характерними $€$ порушення вуглеводного й ліпідного обмінів.

2. За коморбідності з гіпертонічною хворобою або ренопаренхіматозною артеріальною гіпертензією посилюються ці зміни, що може відігравати важливу роль у патогенезі даних захворювань. Показники тригліцеридів та індексу НОМА є достовірно вищими за коморбідності як із гіпертонічною хворобою, так і з ренопаренхіматозною артеріальною гіпертензією $(\mathrm{p}<0,05)$. Показник холестерину ліпопротеїдів низької щільності є достовірно вищим за коморбідності з ренопаренхіматозною артеріальною гіпертензією $(\mathrm{p}<0,05)$.

3. Показники вуглеводного й ліпідного обмінів тісно пов'язані з показниками артеріального тиску, індексів маси тіла та талія / стегно, маркерами ураження печінки, нирковою функцією, а також із тривалістю захворювання. Спектр кореляційних зв'язків є різним у хворих із неалкогольною жировою хворобою печінки та ії коморбідністю з гіпертонічною хворобою або ренопаренхіматозною артеріальною гіпертензією.

4. У разі коморбідності неалкогольної жирової хвороби печінки з гіпертонічною хворобою або ренопаренхіматозною артеріальною гіпертензією, на відміну від ізольованого перебігу, характерними $є$ кореляційні взаємозв'язки між показниками вуглеводного й ліпідного обмінів, з одного боку, та артеріальним тиском і ниркової функції - із другого.

Дані зміни свідчать про найбільший проатерогенний потенціал у пацієнтів із коморбідним перебігом неалкогольної жирової хвороби печінки з гіпертонічною хворобою або ренопаренхіматозною артеріальною гіпертензією, що в поєднанні з порушеннями вуглеводного обміну призводить до значного зростання кардіоваскулярного ризику та цукрового діабету 2-го типу.

Таким чином, визначено особливості вуглеводного й ліпідного обмінів, що спричинюють формування, маніфестацію та прогресування як ізольованої неалкогольної жирової хвороби печінки, так і за коморбідності піi iз гіпертонічною хворобою або ренопаренхіматозною артеріальною гіпертензією.

Перспективами подалыших досліджень $\epsilon$ розробка ефективних диференційованих комплексних схем корекції виявлених порушень.

\section{Список літератури}

1. Byrne C. D. NAFLD: a multisystem disease / C. D. Byrne, G. Targher // J. Hepatol. - 2015. - Vol. 62 (1 suppl.). - S47-64.

2. Perseghin G. Hypertension and hepatic triglycerides content: a two (multi)-faceted clinical challenge? /

G. Perseghin, G. Manzoni, G. Grassi // J. Hypertension. - 2017. - Vol. 35 (4). - P. 715-717.

3. Nonalcoholic fatty liver disease and carotid atherosclerosis in children / L. Pacifico, V. Cantisani, P. Ricci [et al.] // Pediatric Research. - 2008. - Vol. 63, № 4. - P. 423-427.

4. Epicardial fat, cardiac geometry and cardiac function in patients with non-alcoholic fatty liver disease: association with the severity of liver disease / S. Petta, C. Argano, D. Colomba [et al.] // J. Hepatol. - 2015. - Vol. 62 (4). - P. 928-933.

5. Братусь В. В. Ожирение, инсулинорезистентность, метаболический синдром: фундаментальные и клинические аспекты / Братусь В. В., Талаева Т. В., Шумаков В. А. - К. : Четверта хвиля, 2009. $-416 \mathrm{c}$.

6. Relationship between kidney function and liver histology in subjects with nonalcoholic steatohepatitis / G. Targher, L. Bertolini, S. Rodella [et al.] // Clin. J. Am. Soc. Nephrol. - 2010. - Vol. 5. - P. 2166-2171.

7. Особливості вуглеводного та ліпідного обміну у хворих на неалкогольну жирову хворобу печінки залежно від ступеня кардіоваскулярного ризику / О. В. Колеснікова, О. Я. Бабак, Т. А. Соломенцева [та ін.] // Сучасна гастроентерологія. - 2013. - № 6. - С. 7-12. 


\section{References \\ 1. Byrne C.D., Targher G. (2015). NAFLD: a multisystem disease. J. Hepatol., vol. 62 (suppl. 1), S47-} 64.

2. Perseghin G., Manzoni G., Grassi G. (2017). Hypertension and hepatic triglycerides content: a two (multi)-faceted clinical challenge? J. Hypertension, vol. 35 (4), pp. 715-717.

3. Pacifico L., Cantisani V., Ricci P., Osborn J.F., Schiavo E., Anania C. et al. (2008). Nonalcoholic fatty liver disease and carotid atherosclerosis in children. Pediatric Research, vol. 63, № 4, pp. 423-427.

4. Petta S., Argano C., Colomba D., Camma C., Di Marco V., Cabibi D. et al. (2015). Epicardial fat, cardiac geometry and cardiac function in patients with non-alcoholic fatty liver disease: association with the severity of liver disease. J. Hepatol., vol. 62 (4), pp. 928-933.

5. Bratus V.V., Talaieva T.V., Shumakov V.A. (2009). Ozhireniie, insulinorezistentnost, metabolicheskii sindrom: fundamentalnyie i klinicheskiie aspekty [Obesity, insulin resistance, metabolic syndrome: fundamental and clinical aspects]. Kiev: Chetverta khvylia, 416 p. [in Russian].

6. Targher G., Bertolini L., Rodella S., Lippi G., Zoppini G., Chonchol M. (2010). Relationship between kidney function and liver histology in subjects with nonalcoholic steatohepatitis. Clin. J. Am. Soc. Nephrol., vol. 5, pp. 2166-2171.

7. Kolesnikova O.V., Babak O.Ya., Solomentseva T.A., Kurinna O.G., Sytnyk K.O. (2013). Osoblyvosti vuhlevodnoho ta lipidnoho obminu u khvorykh na nealkoholnu zhirovu khvorobu pechinki zalezhno vid stupenia kardiovaskuliarnoho ryzyku [Features of carbohydrate and lipid metabolism in patients with non-alcoholic fatty liver disease depending on the degree of cardiovascular risk]. Suchasna hastroenterolohiia - Modern Gastroenterology, № 6, pp. 7-12 [in Ukrainian].

\section{О.Я. Бабак, К.А. Просоленко, В.И. Молодан, Г.Ю. Панченко, Е.А. Лапшина ОСОБЕННОСТИ НАРУШЕНИЙ УГЛЕВОДНОГО И ЛИПИДНОГО ОБМЕНОВ ПРИ НЕАЛКОГОЛЬНОЙ ЖИРОВОЙ БОЛЕЗНИ ПЕЧЕНИ И ЕЁ КОМОРБИДНОСТИ С АРТЕРИАЛЬНОЙ ГИПЕРТЕНЗИЕЙ}

Исследованы особенности углеводного и липидного обменов при коморбидности неалкогольной жировой болезни печени и гипертонической болезни или ренопаренхиматозной артериальной гипертензии, оценены основные факторы, влияющие на эти показатели. Обследовано 269 пациентов: 60 с неалкогольной жировой болезнью печени, 121 - с коморбидностью таковой и гипертонической болезнью, 88 - с её коморбидностью с ренопаренхиматозной артериальной гипертензией, средний возраст пациентов - $(48,07 \pm 10,81)$ года. Контрольная группа - 20 здоровых лиц, сопоставимых по возрасту и полу с больными. Оценивали антропометрические данные и артериальное давление. Определяли концентрацию липидов крови, аминотрансферазы, гамма-глутамилтранспептидазы, инсулина, гликозилированный гемоглобин и другие биохимические показатели крови, инсулинорезистентность по индексу НОМА, скорость клубочковой фильтрации. Использовали ультразвуковое исследование. Выявлено, что для неалкогольной жировой болезни печени независимо от её коморбидности с гипертонической болезнью или ренопаренхиматозной артериальной гипертензией характерны нарушения углеводного и липидного обменов. Коморбидность вызывает усиление этих изменений и может играть важную роль в патогенезе заболеваний. Показатели триглицеридов и индекса НОМА достоверно выше при коморбидности как с гипертонической болезнью, так и с ренопаренхиматозной артериальной гипертензией. Показатели липопротеидов низкой плотности достоверно выше при коморбидности с ренопаренхиматозной артериальной гипертензией. Показатели углеводного и липидного обменов тесно связаны с показателями артериального давления, индексов массы тела и талия / бедро, маркерами поражения печени, функции почек, а также длительностью заболевания. Спектр корреляционных связей различен у больных с изолированной неалкогольной жировой болезнью печени и при её коморбидности. Для коморбидности характерны корреляционные взаимосвязи между показателями углеводного и липидного обменов, с одной стороны, и показателями артериального давления и почечной функции - с другой. Данные изменения свидетельствуют о проатерогенном потенциале у больных с коморбидным течением болезни, что в сочетании с нарушениями углеводного обмена приводит к значительному росту кардиоваскулярного риска и сахарного диабета 2-го типа.

Ключевые слова: дислипидемия, нарушение углеводного обмена, неалкогольная жировая болезнь печени, артериальная гипертензия. 


\section{O.Ya. Babak, K.O. Prosolenko, V.I. Molodan, G.Yu. Panchenko, K.A. Lapshyna FEATURES OF DISTURBANCES OF CARBOHYDRATE AND LIPID METABOLISM AT NON- ALCOHOLIC FATTY LIVER DISEASE AND AT ITS COMORBIDITY WITH ARTERIAL HYPERTENSION}

The features of carbohydrate and lipid metabolism with comorbidity of non-alcoholic fatty liver disease and hypertension or renoparenchymal arterial hypertension were studied, the main factors affecting these indicators were evaluated. 269 patients were examined: 60 patients have been attacted by non-alcoholic fatty liver disease, 121 patients have been attacted by its comorbidity and hypertension, 88 patients have been attacted by its comorbidity with renoparenchymal arterial hypertension, the average age of the patients was $(48,07 \pm 10,81)$ years. The control group consisted of 20 healthy individuals comparable in age and sex with the sick. Anthropometric data and blood pressure were evaluated. The concentrations of blood lipids, aminotransferase, gamma-glutamyl transpeptidases, insulin, glycosylated hemoglobin and other blood biochemical parameters, insulin resistance by the HOMA index, glomerular filtration rate were determined. Ultrasound wad used. It was revealed that non-alcoholic fatty liver disease, regardless of its comorbidity with hypertension or renoparenchymal arterial hypertension, is characterized by disturbances in carbohydrate and lipid metabolism. Comorbidity causes an increase in these changes and can play an important role in the pathogenesis of diseases. The triglycerides and the NOMA index are significantly higher with comorbidity with both hypertension and renoparenchymal arterial hypertension. The indicators of low density lipoproteins are significantly higher with comorbidity with renoparenchymal arterial hypertension. Indicators of carbohydrate and lipid metabolism are closely related to indicators of blood pressure, body mass and waist / hip indices, markers of liver damage, kidney function, and the duration of the disease. The spectrum of correlation is different in patients with non-alcoholic fatty liver disease and with its comorbidity with hypertension or renoparenchymal arterial hypertension. Comorbidity is characterized by correlation between indicators of carbohydrate and lipid metabolism, on the one hand, and blood pressure and renal function, on the other. These changes indicate a pro-atherogenic potential in patients with a comorbid course of the disease, which, combined with impaired carbohydrate metabolism, leads to a significant increase in cardiovascular risk and diabetes mellitus type 2.

Keywords: dyslipidemia, impaired carbohydrate metabolism, non-alcoholic fatty liver disease, arterial hypertension.

Надійшла 26.03.19

\section{Відомості про авторів}

Бабак Олег Якович - доктор медичних наук, професор, завідувач кафедри внутрішньої медицини № 1 ХНМУ.

Адреса: 61039, м. Харків, пр. Любові Малої, 2а, ДУ «Національний інститут терапії ім. Л.Т. Малої НАМНУ».

Тел.: +38(050)540-26-25.

E-mail: dep.intern.med1@gmail.com.

ORCID: https://orcid.org/0000-0002-3278-663X.

Просоленко Костянтин Олександрович - кандидат медичних наук, доцент кафедри внутрішньої медицини № 1 ХНМУ.

Адреса: 61204, м. Харків, вул. Ахсарова, 13А, кв. 54.

Тел.: +38(067)938-17-27.

E-mail: prosolenko2005@ukr.net.

ORCID: https://orcid.org/0000-0002-3160-6369.

Молодан Володимир Ілліч - кандидат медичних наук, доцент кафедри внутрішньої медицини № 1 ХНМУ.

Адреса: 61039, м. Харків, пр. Любові Малої, 2а, ДУ «Національний інститут терапії ім. Л.Т. Малої НАМНУ

Тел.: +38(050)266-68-37.

E-mail:molodanvi@gmail.com.

ORCID: https://orcid.org/0000-0003-0932-1815. 
Панченко Галина Юрї̈вна - кандидат медичних наук, доцент кафедри внутрішньої медицини № 1 ХНМУ.

Адреса: 61039, м. Харків, пр. Любові Малої, 2а, ДУ «Національний інститут терапії ім. Л.Т. Малої НАМНУ».

Тел.: +38(050)303-05-04.

E-mail: galinapanchenko4@gmail.com.

ORCID: https://orcid.org/0000-0002-0525-6254.

Лапшина Катерина Аркадївна - кандидат медичних наук, асистент кафедри внутрішньої медицини № 1 ХНМУ.

Адреса: 61039, м. Харків, пр. Любові Малої, 2а, ДУ «Національний інститут терапії ім. Л.Т. Малої НАМНУ».

Тел.: +38(066)295-32-14.

E-mail: ekaterinalapshyna@gmail.com.

ORCID: https://orcid.org/0000-0001-5340-3637. 